\title{
Best linear unbiased prediction of herbivore preferences
}

\author{
RICARDO M. RODRIGUEZ IGLESIAS AND MORT M. KOTHMANN
}

Authors are post-doctoral research associate and professor, Department of Rangeland Ecology \& Management, Texas A\&M University, College Station, Tex. $77843-2126$.

\begin{abstract}
Generalized linear mixed models were used to obtain best linear unbiased predictions (BLUP's) of herbivore preferences for range plant species from expert knowledge contained in range site descriptions produced by the USDA Soil Conservation Service (currently Natural Resources Conservation Service). A total of 4,558 assessments of preference for cattle, deer, goats, and sheep on 167 plant species were available from 55 range site descriptions for the Edwards Plateau (Texas). Consistency of predicted preferences was evaluated through intraclass correlation estimated by restricted maximum likelihood. Predictions in observed (3-level ordinal) and logit scales were very similar; rank correlations between predictions in different scales ranged from $0.994(P<0.0001)$ for cattle to $0.998(P<0.0001)$ for sheep. Estimated intraclass correlations were also high (0.74 to 0.84 in observed scale and 0.82 to 0.92 in logit scale) suggesting consistent rankings of plant species across range sites. Metric multidimensional scaling and principal components analysis showed distinct patterns among the 4 herbivores. Grasses and browse were the most informative forage classes for discriminating preferences among herbivores. Deer and cattle exhibited the least similar diet preferences. Sheep and goats were intermediate, with sheep closer to cattle and goats most similar to deer. The pair deer-goat showed the most similar pattern of preferences. BLUP's of plant species preferences showed good agreement with published research on both individual plant species and forage classes. Optimal properties of mixed model procedures can be exploited to predict animal preferences at the range site scale from standardized expert opinion. These estimated preferences may be useful for modeling grazing effects at spatial scales compatible with management decisions.
\end{abstract}

Key Words: BLUP, expert knowledge, diet selection, forage class, generalized linear mixed model, landscape scale

Diet selection in herbivores is a complex function of speciesand individual-specific preferences (Arnold 1981). Factors affecting diet selection include amounts of food on offer, and vegeta-

The senior author acknowledges support received from Texas Agricultural Experiment Station, Consejo Nacional de Investigaciones Científicas y Técnicas (Argentina), Fundación Antorchas (Argentina), and Centro de Recursos Naturales Renovables de la Zona Semiárida (Argentina). Charles A. Taylor (TAES Sonora, Texas), Arthur R. Gilmour (NSW Agriculture, Australia), and an anonymous reviewer made helpful suggestions on a previous version of the manuscript.

Manuscript accepted 17 Jan. 1997.

\section{Resumen}

Se utilizó conocimiento experto, contenido en descripciones de sitio producidas por el USDA Soil Conservation Service (en la actualidad Natural Resources Conservation Service), para predecir preferencias de herbívoros por diferentes especies vegetales aplicando óptima predicción lineal insesgada (OPLI) mediante el ajuste de modelos lineales generalizados mixtos. De 55 descripciones de sitio provenientes del Edwards Plateau (Texas) se recuperaron 4.558 evaluaciones de preferencias de vacunos, ciervos, cabras y ovinos para 167 especies vegetales. La consistencia de las preferencias predichas se evaluó mediante correlación intraclase calculada utilizando máxima verosimilitud restringida. Se obtuvieron predicciones similares en escala de observación (variable ordinal con 3 niveles) y escala logit; las correlaciones de rango entre predicciones en diferentes escalas variaron desde $0,994(\mathrm{P}<0,0001)$ para vacunos hasta $0,998(\mathrm{P}<0,0001)$ para ovinos. Las estimaciones de correlación intraclase también fueron altas (de 0,74 a 0,84 en escala de observación y de 0,82 a 0,92 en escala logit) lo que sugiere un ordenamiento consistente de especies vegetales a través de sitios. Un análisis de componentes y coordenadas principales evidenció diferentes patrones entre los 4 herbívoros. Los pastos y el forraje leñoso aportaron el mayor contenido de información para discriminar entre herbívoros. Ciervos y vacunos exhibieron las más disímiles preferencias. Ovinos y cabras resultaron intermedios, apareciendo los ovinos más cercanos a los vacunos y las cabras más próximas a los ciervos. Cabras y ciervos conformaron el par con preferencias más similares. Las estimaciones de preferencias obtenidas mediante OPLI mostraron buen acuerdo con información previa sobre preferencias por especies vegetales y tipos de forraje. Las óptimas propiedades de los procedimientos de modelo mixto pueden explotarse para predecir preferencias a escala de paisaje a partir de conocimiento experto normalizado. Estas predicciones resultarian útiles para modelar efectos del pastoreo a escalas espaciales compatibles con la adopción de decisiones de manejo.

tion dispersion patterns in time and space. Variables such as season and physiological or life cycle stage of the plant species can also affect preference. Nonetheless, it can be hypothesized that most herbivores would exhibit consistent preferences, at least for some plant species or classes of forage, when the temporal and spatial scales permit the manifestation of such preferences. Selective grazing on preferred species, in turn, may be responsi- 
ble for important shifts in range vegetation composition. Results from diet selection experiments are indicative of preference but are generally fragmentary, limited to local species assemblages, and obviously biased by the kinds, amounts, and distribution of forage on offer.

Range site descriptions produced by the USDA Soil Conservation Service (currently NRCS, Natural Resources Conservation Service) usually contain summaries of expert opinion concerning animal preferences for range plant species. However, the preference status of any plant species within a region is assessed only in a few range sites, i.e., those in which the species occurs frequently. For this reason, direct comparisons among species are only possible within sub-sets of the regional plant species pool. This difficulty may be overcome if enough links can be established among different range sites. Links are provided by widespread plant species whose preference status has been assessed in many range sites. From a connected 2-way array of plant species across range sites it would be possible to produce a general ranking of plant species by statistically accounting for the effects of different range sites. This can be accomplished by using mixed model methodology to produce best linear unbiased predictions (BLUP's) of preferences (Henderson 1984).

This study describes an application of generalized linear mixed model theory for unbalanced data to the problem of producing rankings of animal preferences for range plant species from expert assessments included in range site descriptions. The main objective of this work was to estimate preferences for range plant species at the temporal and spatial scales (i.e., landscape rather than individual plants) embedded in range site descriptions. A range site scale is temporally coarse enough to obscure seasonal shifts in preferences and spatially broad enough to reflect preferences relevant to the size of management units. Such preferences may be key components for modeling the effect of grazing on many vegetation parameters at a spatial scale compatible with management decisions (Rodríguez Iglesias 1996).

\section{Materials and Methods}

\section{Source of Data}

Data were compiled from range site descriptions produced by the USDA Soil Conservation Service (currently NRCS; Agency Manuals 1972-1976) for the Edwards Plateau, Texas. Most range site descriptions for the region contain lists of plant species classified by preference for cattle, deer, goats, and sheep. Plant species are evaluated in an ordinal scale of grazing preference as primary (grazed first), secondary (second choice forage), or low value (rarely used or usually not accessible to grazers/ browsers). The procedure of expert opinion elicitation was informal and can be described as one in which many groups of knowledgeable Range Conservationists were consulted and produced opinion on preferences for 1 or more range sites. Expertise was not systematically tested for accuracy or consistency. This procedure is different from the current approach at NRCS that involves the use of a "master list" of preferences from which preferences at the range site level are derived.

A total of 167 plant species (or groups thereof, e.g., sedges), occurring in at least 3 different range sites, were considered for analysis. A checklist of common names was produced from the range site descriptions and examined for duplications and taxonomic consistency using published information for the region
(Correl and Johnston 1970, Hatch et al. 1990). Total numbers of range site descriptions and plant species included in the data sets for each animal species are shown in Table 1. The number of plant species included in each preference list frequently differed for the 4 animal species within a range site. It averaged about 22 plant species/ herbivore when plant species were constrained to have been assessed for preference in at least 3 different range sites (Table 1).

\section{Data Structure and Connectedness}

The information extracted from range site descriptions was arranged for analysis in 4 arrays (i.e., 1 for each animal species) of plant species by sites. As range site descriptions rarely included more than 40 plant species for any herbivore, data sets of plant species by sites were sparse with an average of $18.8 \%$ of filled cells (Table 1).

Table 1. Description of the data sets compiled for cattle, deer, goats and sheep.

\begin{tabular}{|c|c|c|c|c|c|}
\hline & Cattle & Deer & Goats & Sheep & $\begin{array}{c}\text { Average } \\
\text { or } \\
\text { Total }\end{array}$ \\
\hline Number of range sites & 55 & 52 & 47 & 53 & 55 \\
\hline Number of data & 1,320 & 928 & 988 & 1,322 & 4,558 \\
\hline Number of groups ${ }^{1}$ & 115 & 113 & 115 & 129 & 167 \\
\hline $\begin{array}{l}\text { Mean number of } \\
\text { groups } 1 / \text { range site }\end{array}$ & 24.0 & 17.8 & 21.0 & 24.9 & 22.3 \\
\hline Percentage of filled cells & s 20.9 & 15.8 & 18.3 & 19.3 & 18.8 \\
\hline
\end{tabular}

${ }^{1}$ Plant species, genus, or groups of plant species (e.g., sedges, cactii).

Checking for connectedness in a sparse array is necessary to ensure that the rank of the design matrix (i.e., the matrix that describes the structure of the problem in terms of how experimental units are arranged in the context of factors considered in the model) is correct. Intuitively, it will not make sense to compare plant species A with plant species B if no path can be established in the 2-way array when moving from A to B (or vice versa) through filled cells in the array. Consider the diagram in Figure 1. The arrows indicate one of the possible pathways connecting species $B$ and $F$. Applying the same procedure to the rest of possible combinations shows that $\mathrm{E}$ (with information limited to site 5) is the only disconnected species in the array. An equivalent approach is to record all possible pairs of comparisons and verify if some kind of chaining can be established through common links. For the B-F example, $\mathrm{B}$ can be compared to $\mathrm{C}$ in site 2, $C$ can be compared to $D$ in site 4 , and $D$ can be compared to $F$ in site 3 , which completes the chain. Connectedness between species across sites was verified (Weeks and Williams 1964) for each data set prior to analysis. For a 2-way classification (e.g., plant species by range sites) the procedure described by Weeks and Williams (1964) provides both necessary and sufficient conditions for connectedness.

\section{Statistical Models and BLUP}

Best Linear Unbiased Prediction (BLUP) methodology was developed in the animal breeding arena for the purpose of predicting breeding values from unbalanced (usually incomplete) information gathered from management settings, as opposed to data coming from well-designed, balanced, experiments. The idea 


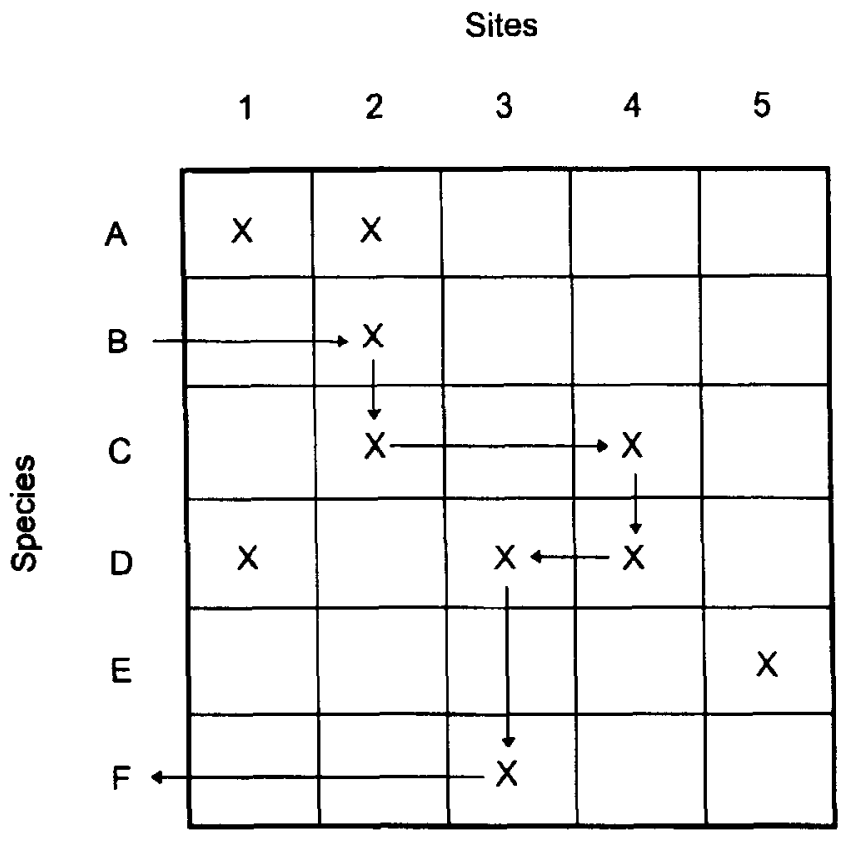

Fig. 1. Example of connectedness for a $6 \times 5$ array of species by sites. Crosses indicate cells that contain information. Arrows show a path connecting species $B$ and $F$.

behind predicting effects that would exhibit BLUP properties is quite simple, although the numeric computations can be extensive. Suppose that we want to compare the value of a series of household items. A simple approach would be to visit a number of stores and ask for the prices of those items. That would provide us with a series of numbers (i.e., prices of items classified in an array of items by stores) that supposedly reflect 2 things: the "true" value of the items and the variability introduced by the pricing policies of different stores. We would probably be tempted to take average prices across stores as valid estimates of the value of the items. However, it is also probable that we were not able to collect prices for every item at every store. In this latter case, the "average price approach" would be incorrect because of both different pricing policies in different stores and lack of information for certain items in certain stores. What we obviously need is some methodology that removes the effect of the stores and allow us to estimate the value of the items free from such an influence. This is exactly what BLUP methods do.

Two related approaches were used to produce rankings of plant species according to preference for the 4 animal species. Both approaches are standard procedures for solving the analogous problem of predicting random genetic effects in animals when predictions involve removing fixed effects (Henderson 1984). In both approaches, in which sites were treated as fixed effects and plant species as random effects, generalized linear mixed models (GLMM) were used to explain variation in preferences. When linear models are formulated in compact matrix notation it becomes apparent that the only difference between a "regression" and an "analysis of variance" setting is the structure of the design matrix (see above). For this reason, regression and analysis of variance models are usually considered instances of what is known as "general linear model". Error distributions in general linear models are usually assumed to be normal for inference purposes. Relaxing this latter constrain to include a family of expo- nential distributions (including binomial, Poisson, gamma, etc.) generates an even more inclusive kind of statistical models known as "generalized linear models" (Nelder and Wedderburn 1972). At any level in this hierarchy, the model may contain fixed and/ or random effects. When both fixed and random effects are included we have a "mixed model". In this latter case, a common goal is to estimate the realized value of the random effects (i.e., to "predict" the random effects) free from the constrains imposed by the fixed effects. When the prediction of random effects in a mixed model involves an error distribution other than normal, we call the resulting model a "generalized linear mixed model". For our problem, GLMM solutions provide best (i.e., minimum prediction error variance) linear unbiased predictions (BLUP's) for the random effects (i.e., plant species) given the statistical removal of fixed effects (i.e., range sites). When a normal error distribution holds, a BLUP approach maximizes the probability of producing a correct pair-wise ranking of random effects (Henderson 1984). A separate analysis was done for each animal species. Ranks derived from predictions from the 2 approaches were compared using Spearman's rank correlation coefficient.

In the first approach, the response variable preference was an ordinal scale with 3 levels (coded 1,2,3) corresponding to primary, secondary, and low value forage. The MIXED procedure in SAS version 6.08 (SAS Institute Inc. 1989) was used to obtain BLUP's of preference for each plant species. An estimate of the ratio between the variance of the random effects and the variance of the error term is necessary to derive BLUP solutions. Variance ratios were regarded as unknown and restricted maximum likelihood estimates (Patterson and Thompson 1971) of them were obtained from the same data sets. Intraclass correlations, which measure the strength of the association between different instances of the same random effects (i.e., plant species) across fixed effects (i.e., range site descriptions), were calculated using the estimated variances. In the framework of generalized linear models (McCullagh and Nelder 1989), this first approach is equivalent to fitting a linear mixed model with normal errors and identity link function.

The second approach, based on Gilmour et al. (1987), assumes that preference is continuous on some underlying scale but is observed as classes separated by fixed thresholds. The GLMM setting used to solve the prediction problem is analogous to the model utilized in the first approach, except for the use of a multinomial error distribution and probit or logit link functions. Random effects are predicted using quasi-likelihood solutions for the fixed effects. More detailed descriptions of this second approach can be found in Gilmour et al. (1987) and Meuwissen et al. (1995). Our analysis was implemented in logit scale with the response variable coded as multinomial, i.e., 3 dummy variables were used instead of the single-variable ordinal coding. The maximum likelihood routines implemented in REG (Gilmour 1985) version 94.10 were used for calculations. For the interested reader, Robinson (1991) offers an excellent review on BLUP theory and current applications including Kalman filtering, credibility theory, kriging, small-area estimation, quality measurement, and noise removal from images.

\section{Preference Comparisons Among Animal Species}

Similarities in preference among animal species were studied for both individual plant species and classes of forage (grasses, forbs, browse, and others) using principal components analysis of 
the correlation matrix and metric multidimensional scaling (also known as principal coordinate analysis) of distance matrices derived from correlations. The princomp and cmdscale functions in S-Plus version 3.2 (Statistical Sciences Inc. 1993) were used for these analyses, respectively.

\section{Comparisons with Published Data}

For all 4 animal species, preference rankings for forage classes (grasses, forbs, browse, and others) were generated from best linear unbiased predictions for individual plant species and compared to previously published data for the region (Bryant et al. 1979, Rector 1983) to examine consistency and agreement. For deer preferences, published information (Armstrong 1991) allowed comparisons to be performed on an individual plant species basis.

\section{Results and Discussion}

Preference data extracted from the range site descriptions for this study are of a non-experimental nature. This imposes limitations on the type and quality of inferences that can be generated. Any bias or relative weighting embedded into those descriptions is not observable and, consequently, cannot be accounted for. In particular, it is likely that some correlation among random effects (i.e., plant species) was introduced due to the non-independent nature of the expert opinion elicited at different range sites. In statistical terms, the covariance matrix of random effects is no longer diagonal as it is assumed in the analyses performed. Given these limitations, this BLUP application should be considered a meta-analysis (Hunter et al. 1982; see also Stram 1996 for a description on the use of mixed-effects models for meta-analysis of published data) of information that was compiled and summarized in a comparable way for the same animal and plant species in different environments. Optimal properties of BLUP methodology (Henderson 1984, Gilmour et al. 1987, Thompson 1990) guarantee the generation of the best (in the sense of least variable) predictions possible, given the data. However, results should be considered with caution for 2 main reasons. Firstly, because they strictly apply to some property of plant species (attractiveness as a source of food) that was evaluated by experts at the landscape scale rather than experimentally estimated. Secondly, because the nature of the expert elicitation process was not systematic and can not be accounted for to remove possible correlation structures induced.

High intraclass correlations were estimated in both observed and logit scales. They ranged from 0.74 (sheep data set) to 0.84 (cattle data set) in the observed scale and from 0.82 (sheep data set) to 0.92 (cattle data set) in the logit scale. These results indicate a highly consistent ranking of species across sites; i.e., plant species tended to repeat their relative order across range sites independent of any range site effect. In the minds of the experts that produced the range site descriptions, animal preferences at the range site scale are only slightly affected by particular botanical compositions or any other attribute used to characterize different range sites. Rankings of plant species preferences in the range site descriptions changed from site to site according to the particular local plant assemblage. Yet, general rankings were consistent, with only very minor exceptions. If species A was more preferred than species B in a given site, it was also equally or more preferred than species $B$ in the rest of the sites. This condition is required to hypothesize any general preference ranking of plant species and is satisfied in these range site descriptions. As indicated above, however, high intraclass correlations may have heen induced in part by non-independence of the expert sources. The fewer the number of experts consulted and the larger the overlapping of opinions across sites, the higher the upward bias that may be expected.

\section{BLUP Prediction of Preferences}

Predicted random effects, and consequently preference ranks of plant species in observed and logit scales, were similar for each of the 4 animal species. Correlations between ranks in both scales were very high, ranging from $0.994(\mathrm{P}<0.0001)$ for cattle to $0.998(\mathrm{P}<0.0001)$ for sheep. Despite this general agreement, there were some shifts in the relative rankings of individual species. The average number of position shifts in the ranked lists was $1.6 \pm 0.46$ (mean \pm standard deviation), $1.7 \pm 0.47,1.4 \pm$ 0.46 , and $1.4 \pm 0.46$ for cattle, deer, goats, and sheep, with extreme shifts involving $8,8,7$, and 8 positions, respectively. The significance of these shifts in ranking depends on which approach is considered more appropriate for the problem and on the importance of those individual shifts. As the intraclass correlation increases, the advantage of predicting random effects in some underlying scale tends to disappear (Gilmour et al. 1987) because both sets of solutions tend to converge. However, the multinomial nature of the response still suggests the convenience of predicting random effects directly on the underlying scale to better satisfy the distributional assumptions (Gilmour et al. 1985, 1987). Preference rankings for individual species (or groups of species) determined from predictions in logit scale are shown in Table 2. These rankings (as well as the original predictions) should be interpreted as general indicators for grazing preferences at a landscape scale. They may have various applications in management and modeling for representing the expected grazing impact of different herbivores, anticipating grazing-induced vegetation trends, etc. Compare, for example (Table 2), the preference rankings of yellow indiangrass (Sorghastrum nutans (L.) Nash) (ranked in first place for cattle, moderately preferred by sheep and goats, and of low preference for deer) to those for bundleflower species (Desmanthus spp. Willd.) and velvet bundleflower (D. velutinus Scheele) (highly preferred by sheep and goats, preferred by deer, but only mid-ranking for cattle preference).

\section{Preference Comparisons Among Animal Species}

Principal components were extracted from a data set of 66 plant species with complete preference predictions for the 4 animal species (Table 2). Figure 2 is a biplot (Gabriel 1971, Gower and Hand 1996) that summarizes the most relevant information relative to the original variables (animal preferences represented by arrows oriented toward increased preference) and the transformed observations (principal component scores for the 66 plant species). The first principal component (which accounted for 78 $\%$ of the variability in preference) can be interpreted as a general axis that summarizes common preferences exhibited by the 4 animal species. Distribution of plant species along this first axis ranged from those highly preferred by all 4 herbivores (right extreme) to those generally rejected by any of the 4 animal species (left extreme). Plant species tended to cluster at both extremes of the distribution. This bimodal marginal distribution of principal component scores suggests a general preference for certain species with consistently low rankings (i.e., high prefer- 
Table 2. Ranks from best linear unbiased predictions in logit scale. Under ID heading, F, G, B, and $O$, stand for forb, grass, browse, and other, respectively. $N$ indicates number of data for cattle (C), deer (D), goats (G), and sheep (S).

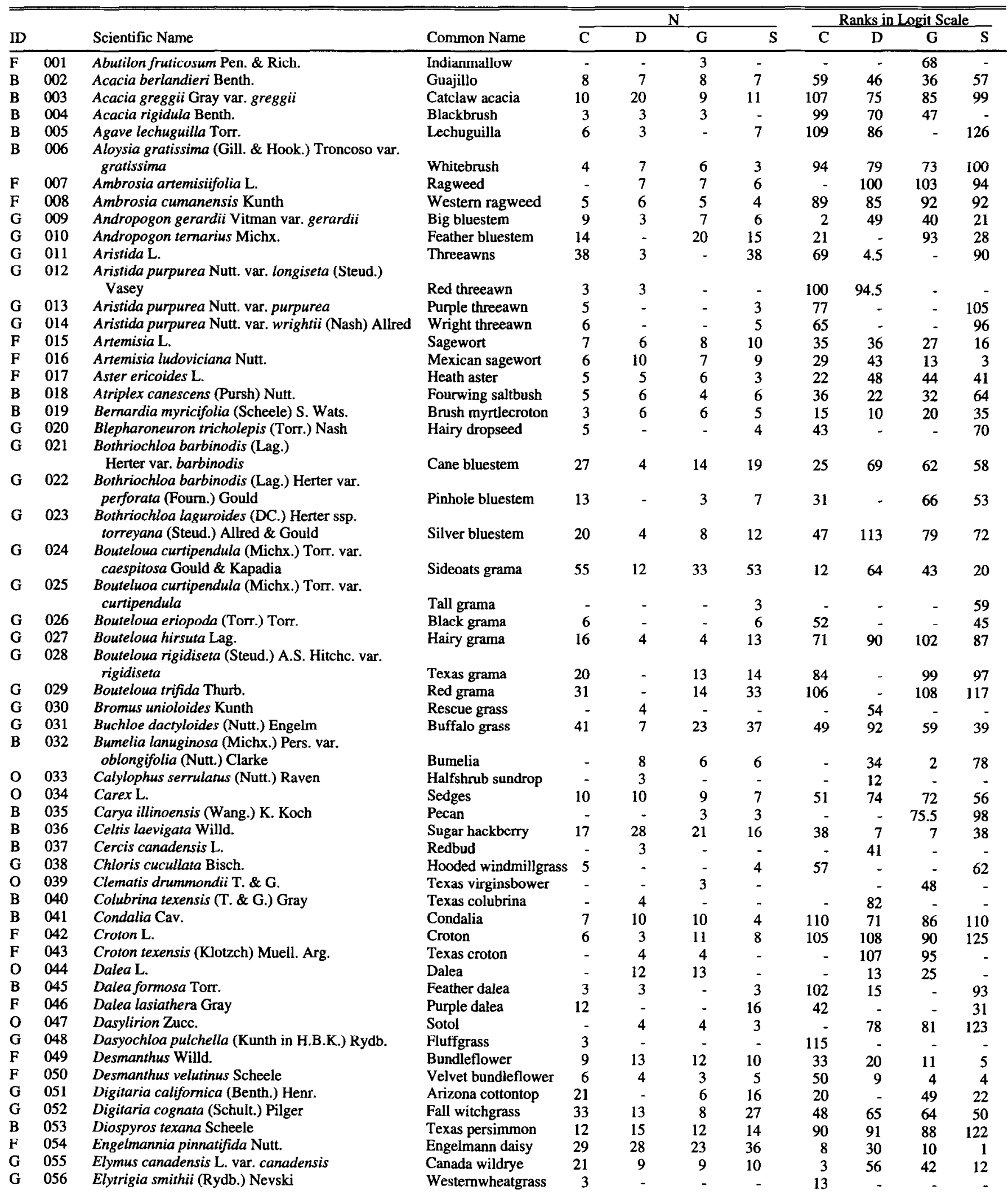




\begin{tabular}{|c|c|c|c|c|c|c|c|c|c|c|c|}
\hline \multirow[b]{2}{*}{ ID } & & \multirow[b]{2}{*}{ Scientific Name } & \multirow[b]{2}{*}{ Common Name } & \multicolumn{4}{|c|}{$\mathrm{N}$} & \multicolumn{4}{|c|}{ Ranks in Logit Scale } \\
\hline & & & & $\bar{C}$ & $\mathrm{D}$ & G & $\bar{S}$ & $\overline{\mathrm{C}}$ & D & $G$ & $S$ \\
\hline B & 057 & Ephedra L. & Ephedra & 7 & 11 & 5 & 9 & 55 & 29 & 19 & 47 \\
\hline B & 058 & Ephedra antisyphilitica C.A. Mcycr & Vinc ephedra & 6 & 6 & 6 & 6 & 27 & 26 & 24 & 23 \\
\hline $\mathbf{G}$ & 059 & Eragrostis curtipedicellata Buckl. & Gummy lovegrass & 3 & - & - & - & 85 & - & - & - \\
\hline $\mathbf{G}$ & 060 & Eragrostis intermedia A.S. Hitchc. & Plains lovegrass & 17 & - & 7 & 19 & 7 & - & 37 & 19 \\
\hline G & 061 & Eragrostis palmeri S. Wats. & Rio Grande lovegrass & 3 & - & - & - & 18 & - & - & - \\
\hline $\mathbf{G}$ & 062 & Eragrostis trichodes (Nutt.) Wood & Sand lovegrass & 4 & - & - & 3 & 6 & - & - & 36 \\
\hline G & 063 & Eriochloa sericea (Scheele) Munro & Texas cupgrass & 16 & - & 5 & 11 & 9 & - & 61 & 40 \\
\hline $\mathrm{O}$ & 064 & Eriogonum longifolium Nutt. & Wild buckwheat & - & 3 & - & - & - & 60 & - & - \\
\hline $\mathbf{G}$ & 065 & Erioneuron pilosum (Buckl.) Nash & Hairy tridens & 24 & - & 13 & 26 & 104 & - & 97 & 95 \\
\hline $\mathbf{F}$ & 066 & Erodium Soland. & Filaree & 3 & 3 & - & 4 & 40 & 51 & - & 30 \\
\hline $\mathbf{F}$ & 067 & Euphorbia L. & Euphorbia & - & 3 & - & - & - & 45 & - & - \\
\hline $\mathrm{F}$ & 068 & Evax Gaertn. & Evax & - & - & 4 & 6 & - & - & 110 & 124 \\
\hline B & 069 & Eysenhardtia texana Scheele & Texas kidneywood & 10 & 19 & 19 & 14 & 23 & 2 & 8 & 15 \\
\hline B & 070 & Fluorensia cernua DC. & Tarbush & 3 & 3 & 4 & 4 & 112 & 105 & 82 & 104 \\
\hline B & 071 & Forestiera pubescens Nutt. & Elbowbush & 4 & 10 & 9 & 6 & 76 & 25 & 35 & 83 \\
\hline $\mathbf{F}$ & 072 & Gaura L. & Gaura & 8 & 19 & 10 & 16 & 39 & 19 & 18 & 17 \\
\hline B & 073 & Guaiacum angustifolium Engelm. & Guayacan & 3 & 3 & 3 & 3 & 64 & 31 & 29 & 68 \\
\hline $\mathbf{O}$ & 074 & Gutierrezia sarothrae (Pursh) Britt. \& Rusby & Broom snakeweed & - & 5 & 5 & 8 & - & 77 & 111 & 101 \\
\hline $\mathbf{F}$ & 075 & Helenium L. & Sneezeweed & - & 3 & 4 & 4 & - & 101 & 96 & 107 \\
\hline $\mathbf{F}$ & 076 & Helianthus maximiliani Schrad. & Maximilian sunflower & 4 & 4 & 3 & 4 & 16 & 57 & 1 & 2 \\
\hline G & 077 & Heteropogon contortus (L.) Beauv. & Tanglehead & 4 & - & - & 4 & 17 & - & - & 71 \\
\hline G & 078 & Hilaria belangeri (Steud.) Nash & Common curty mesquite & 28 & - & 12 & 26 & 54 & - & 80 & 80 \\
\hline G & 079 & Hilaria mutica (Buckl.) Benth. & Tobosagrass & 9 & - & 4 & 9 & 56 & - & 113 & 89 \\
\hline F & 080 & Hymenopappus tenuifolius Pursh & Chalkhill woolly-white & - & 3 & 3 & 3 & - & 21 & 21 & 11 \\
\hline $\mathrm{F}$ & 081 & Hymenoxis odorata DC. & Western bitterweed & - & - & - & 4 & - & - & - & 103 \\
\hline \multirow[t]{2}{*}{$\mathrm{F}$} & 082 & Indigofera miniata Ort. var. leptosepala (Nutt.) & & & & & & & & & \\
\hline & & B. Turner & Western indigo & - & 3 & - & - & - & 39 & - & - \\
\hline B & 083 & Jatropha dioica Cerv. var. dioica & Leatherstem & - & 3 & 3 & 4 & - & 98 & 100 & 121 \\
\hline B & 084 & Juglans $\mathbf{L}$. & Walnut & - & - & 3 & - & - & - & 75.5 & 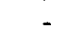 \\
\hline B & 085 & Juniperus L. & Juniper & 5 & 12 & 9 & 6 & 92 & 97 & 91 & 119 \\
\hline $\mathrm{B}$ & 086 & Juniperus ashei Buchholz & Ashe juniper & 7 & 7 & 6 & 7 & 95 & 104 & 101 & 112 \\
\hline $\mathbf{F}$ & 087 & Krameria lanceolata Torr. & Trailing ratany & 5 & 7 & 5 & 4 & 30 & 42 & 45 & 34 \\
\hline B & 088 & Krameria pauciflora Benth. & Range ratany & 3 & 4 & 3 & 4 & 62 & 50 & 22 & 77 \\
\hline B & 089 & Larrea tridentata (DC.) Cov. & Creosotebush & 3 & 5 & 4 & 6 & 114 & 110 & 115 & 129 \\
\hline $\mathbf{G}$ & 090 & Leptochloa dubia (Kunth) Nees & Green sprangletop & 23 & - & 10 & 15 & 5 & - & 46 & 14 \\
\hline $\mathbf{B}$ & 091 & Leucophyllum frutescens (Berl.) I.M. Johnst. & Cenizo & 5 & 6 & 6 & 6 & 111 & 73 & 65 & 81 \\
\hline $\mathrm{F}$ & 092 & Liatris punctata Hook. var. punctata & Dotted gayfeather & 3 & 6 & - & 3 & 72 & 47 & - & 51 \\
\hline B & 093 & Lonicera albiflora T. \& G. & Honeysuckle & - & 5 & 5 & 3 & - & 1 & 6 & 33 \\
\hline B & 094 & Lycium L. & Wolfberry & - & 4 & - & - & - & 81 & - & - \\
\hline B & 095 & Mahonia trifoliolata (Moric.) Fedde & Agarito & 6 & 12 & 10 & 10 & 88 & 93 & 83 & 115 \\
\hline$F$ & 096 & Malva neglecta Wallr. & Common mallow & - & 4 & 4 & 6 & - & 18 & 58 & 6 \\
\hline $\mathrm{O}$ & 097 & Menodora H. \& B. & Menodora & 3 & 4 & 3 & 5 & 46 & 38 & 26 & 32 \\
\hline B & 098 & Mimosa biuncifera Benth. & Catclaw mimosa & - & - & 3 & - & - & - & 60 & - \\
\hline G & 099 & Muhlenberghia arenacea (Buckl.) A.S. Hitchc. & Ear muhly & 3 & - & - & - & 103 & - & - & - \\
\hline G & 100 & Muhlenberghia arenicola $\mathrm{Buckl}$. & Sand muhly & 3 & - & - & - & 68 & - & - & - \\
\hline G & 101 & Muhlenberghia lindheimeri A.S. Hitchc. & Lindheimer muhly & - & - & - & 3 & - & - & - & 102 \\
\hline G & 102 & Muhlenberghia porteri Scribn. & Bush muhly & 12 & - & - & 10 & 28 & - & - & 26 \\
\hline $\mathrm{O}$ & 103 & Nolina texana $\mathrm{S}$. Wats. & Sacahuista & 3 & - & 3 & - & 73 & - & 94 & - \\
\hline $\mathrm{F}$ & 104 & Oenothera speciosa Nutt. & Evening primrose & 3 & 7 & 4 & 5 & 44 & 16 & 31 & 27 \\
\hline B & 105 & Opuntia leptocaulis DC. & Tasajillo & 5 & 6 & 8 & 4 & 87 & 103 & 98 & 116 \\
\hline B & 106 & Opuntia lindheimeri Engelm. var. lindheimeri & Texas pricklypear & 11 & 9 & 14 & 12 & 91 & 96 & 107 & 120 \\
\hline$G$ & 107 & Panicum hallii Vasey var. hallii & Halls panicum & 16 & - & 3 & 8 & 70 & - & 69 & 86 \\
\hline G & 108 & Panicum obtusum Kunth & Vine mesquite & 30 & 3 & 18 & 25 & 26 & 84 & 67 & 49 \\
\hline G & 109 & Panicum virgatum $\mathrm{L}$. & Switchgrass & 6 & - & - & 4 & 11 & - & - & 65 \\
\hline $\mathrm{O}$ & 110 & Phyllanthus polygonoides Spreng. & Knotweed leafflower & - & 8 & 8 & 8 & - & 5 & 28 & 18 \\
\hline $\mathbf{F}$ & 111 & Plantago L. & Plantain & - & 3 & - & - & - & 23 & - & - \\
\hline $\mathbf{G}$ & 112 & Poa L. & Bluegrass & 4 & - & - & 3 & 19 & - & - & 9 \\
\hline B & 113 & Prosopis glandulosa Torr. var. glandulosa & Honey mesquite & 20 & 14 & 11 & 17 & 101 & 112 & 106 & 118 \\
\hline $\mathbf{F}$ & 114 & Psoralidium tenuiflorum (Pursh) Rydb. & Scurfpea & - & 3 & - & 3 & - & 44 & - & 69 \\
\hline B & 115 & Quercus L. & Oak & 11 & 5 & 5 & 8 & 78 & 55 & 52 & 88 \\
\hline B & 116 & Quercus buckleyi Nixon \& Dorr & Texas red oak & - & 7 & 5 & 3 & - & 3 & 16 & 84 \\
\hline \multirow[t]{2}{*}{ B } & 117 & Quercus pungens Liebm. & Sandpaper/ & & & & & & & & \\
\hline & & & Vasey shin oak & 4 & 10 & 9 & 5 & 74 & 37 & 9 & 75 \\
\hline $\mathbf{B}$ & 118 & Quercus stellata Wang. & Post oak & 4 & 6 & 7 & 6 & 83 & 72 & 50 & 114 \\
\hline B & 119 & Quercus virginiana Mill. & Live oak & 17 & 30 & 26 & 20 & 67 & 61 & 30 & 79 \\
\hline $\mathbf{F}$ & 120 & Ratibida Raf. & Prairie coneflower & - & 3 & 3 & 4 & - & 87 & 87 & 91 \\
\hline B & 121 & Rhus L. & Sumac & 5 & 7 & 6 & - & 93 & 58 & 39 & - \\
\hline B & 122 & Rhus aromatica Ait. var. flabelliformis Shinners & Skunkbush sumac & - & 4 & 4 & - & - & 14 & 14 & - \\
\hline
\end{tabular}




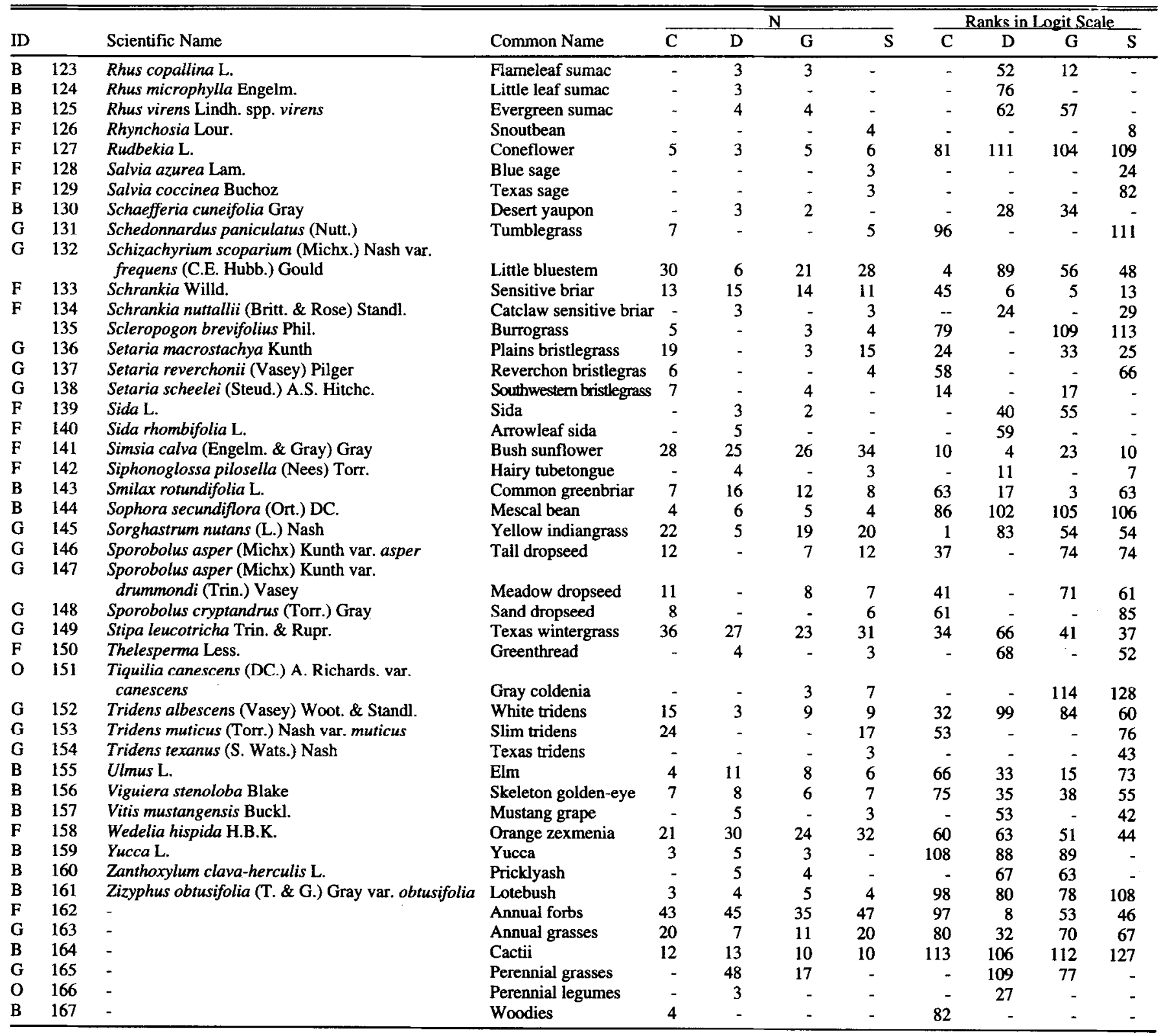

ence) by all 4 animal species (e.g., F141 Bush sunflower [Simsia calva (Engelm. \& Gray) Gray], F054 Engelmann daisy [Engelmannia pinnatifida Nutt.], F076 Maximilian sunflower [Helianthus maximiliani Schrad.], B069 Texas kidneywood [Eysenhardtia texana Scheele]) and general rejection of other plant species (e.g., B089 Creosotebush [Larrea tridentata (DC.) Cov.], B164 Cactii, F127 Coneflower [Rudbekia L.], B070 Tarbush [Fluorensia cernua DC.] ) which ranked consistently high (i.e., low preference) for all 4 herbivores. Common preferences may be important in determining the fate of some highly preferred species that would experience heavy grazing pressure under any possible combination of herbivores. The second axis (accounting for an additional $19 \%$ of total variability) clearly separated grasses (mostly in the upper portion, except for the group of annual grasses [G163]) from woody species (mostly in the lower portion).
The length of the arrows in Fig. 2 indicates the proportion of variance in each variable that is explained by the first 2 principal components; inclination of the arrows is proportional to the loadings for each variable (i.e., to the weight that each variable receives in the formulation of the principal component). Thus, extracted variability was higher for cattle and goats than for deer and sheep. Animal species with larger loadings have more influence in determining the distribution of individual plant species in the 2-dimensional space of preferences shown in Fig. 2. Looking at the orientation of the arrows it is clear that 1) there were common general preferences among the 4 herbivores because all arrows have positive projections on the first axis, 2) cattle and deer exhibited the most dissimilar preferences while sheep and goats were intermediate, and 3) deer and goats form the pair with 


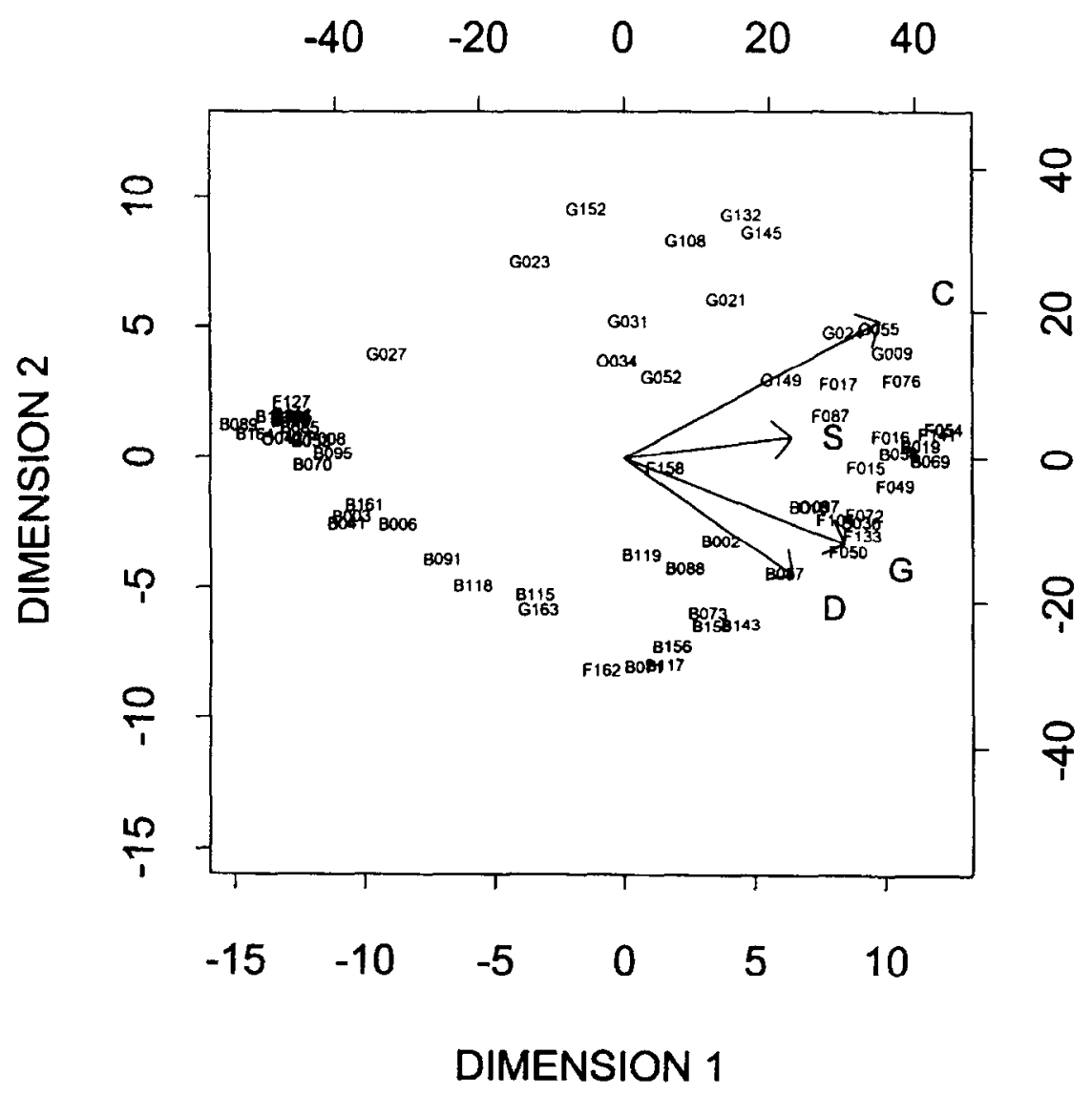

Fig. 2. Biplot of variables and principal component scores. Plant species are identified as grasses (G_), forbs (F), woody plants (W_), and others ( $(O)$ ). Species ID codes are from Table 2 . Arrows point toward increased preferences. Length and inclination of arrows are proportional to variance explained and loading, respectively, for each variable (i.e., predicted preference for cattle (C), deer (D), goats (G), and sheep (S), respectively). To improve visualization, different scaling factors (compare top-right vs. bottom-left) are used for species and variables.

most similar preferences. The projection of the arrows on the second grass-browse axis suggests that cattle and sheep preferences tend to increase in the same direction in which deer and goat preferences decrease. In other words, after accounting for general preferences that favor certain plant species, cattle and sheep will tend to prefer grasses while deer and goats will tend to prefer woody plants.

Rank correlations between preferences for plant species classified by forage classes were highly significant for most pairs of animal species (Table 3). Correlations involving deer and grasses tended to be lower than the rest, or in other words, preferences for individual grass species were least similar when comparisons involved deer (Table 3). Estimated values for rank correlations calculated for pairs of herbivores when all plant species were included (Table 3 ) were also highly significant $(P<0.0001)$. Similar preferences across animal species have been observed before for classes of forage, species, and sex within species in dioecious plants (Straka 1993).

Overall rank correlations calculated for the complete set of plant species (Table 3 ) followed the same pattern observed in the principal components analysis (Fig. 2). Animal species with most similar preferences were deer and goats, mainly because of their similar preferences for woody species and forbs. Cattle and sheep showed similar preferences for all 3 classes of forage. The most dissimilar pair, cattle and deer, primarily differed in their preferences for grass species.
Correlations measure similarity in preferences among animal species; the complements of these correlations (i.e., 1-correlation) can be interpreted as linear distances using metric multidimensional scaling. The first 2 principal components extracted accounted for $97 \%$ of total variation in preferences. Thus, multidimensional scaling in 2 dimensions was applied to each forage class and to the whole set of plant species (Fig. 3). Similar patterns were observed for the 3 groups of plant species. Cattle and deer always showed up in extreme positions. Sheep and goats were either intermediate or closer to one or the other extreme (or to each other) depending upon the forage class considered. Similarities among herbivores when all plant species were considered (Fig. 3d) showed the same pattern observed in the biplot of principal component scores (Fig. 2).

Table 3. Rank correlations among pairs of animal species (C cattle, $D$ deer, $G$ goats, $S$ sheep) for 3 classes of forage and overall correlations calculated including all plant species $(P<0.0001)$ unless otherwise indicated).

\begin{tabular}{lcccc}
\hline \hline Pair & Grasses & Forbs & Browse & Overall \\
\hline C - D & $0.20^{1}$ & $0.50^{2}$ & 0.78 & 0.45 \\
C - G & 0.75 & $0.77^{3}$ & 0.78 & 0.57 \\
C - S & 0.83 & 0.82 & 0.88 & 0.83 \\
D - G & $0.55^{4}$ & 0.84 & 0.93 & 0.87 \\
D - S & 0.48 & 0.87 & 0.85 & 0.71 \\
G - S & 0.86 & 0.94 & 0.85 & 0.76 \\
\hline${ }^{5} \mathrm{P}=0.464 ;{ }^{5} \mathrm{P}=0.028:{ }^{3} \mathrm{P}=0.0003:{ }^{4} \mathrm{P}=0.035:{ }^{5} \mathrm{P}=0.067$ &
\end{tabular}

${ }^{1} \mathrm{P}=0.464 ;{ }^{2} \mathrm{P}=0.028 ;{ }^{3} \mathrm{P}=0.0003 ;{ }^{4} \mathrm{P}=0.035 ;{ }^{5} \mathrm{P}=0.067$. 

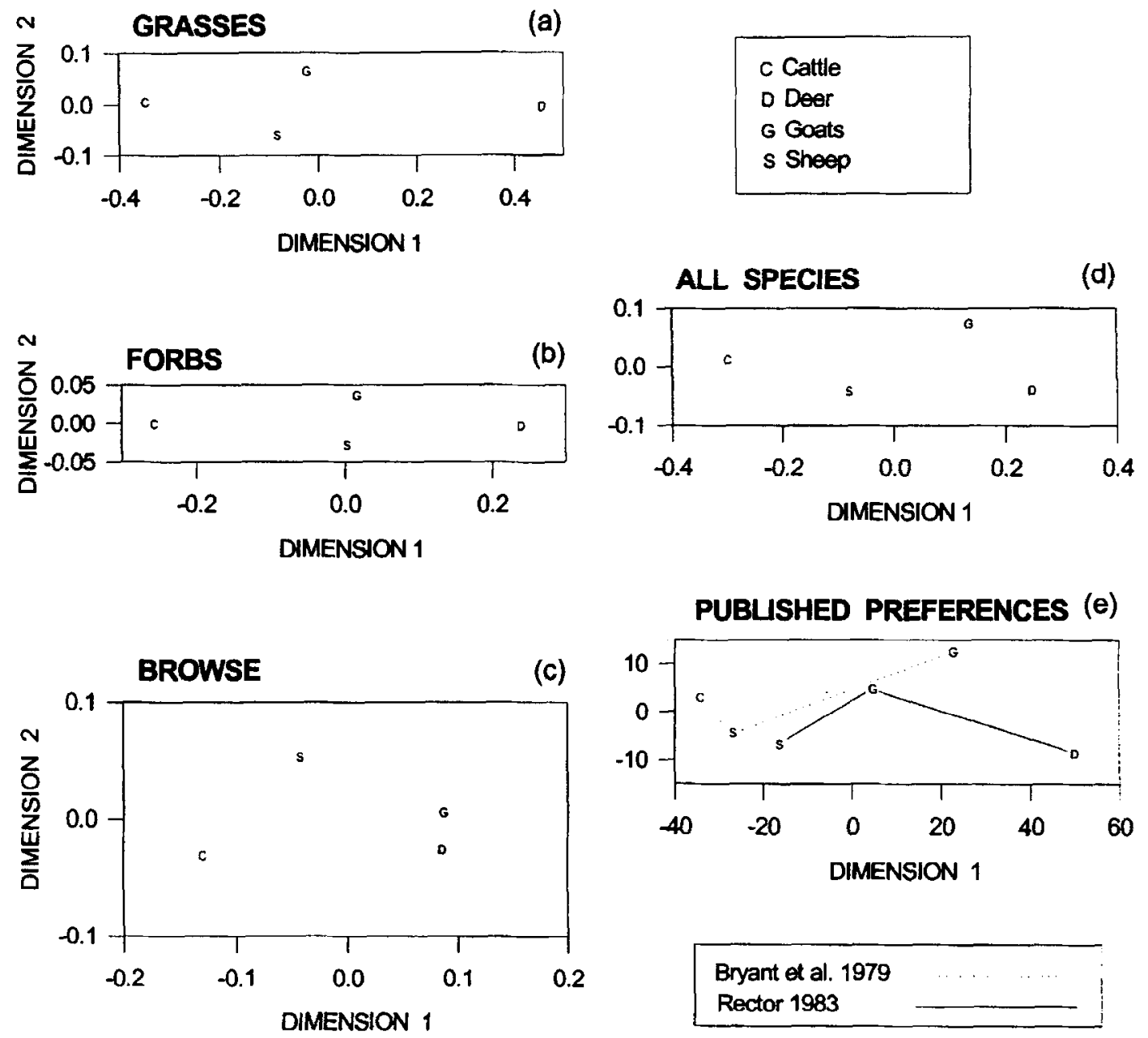

Fig. 3. Metric multidimensional scaling plots of preferences for 3 forage classes: grasses (a), forbs (b), and browse (c) and for all species involved (d). Patterns of previously published preference data (e) are also shown.

Diet selection by free-ranging herbivores usually deviates from individual plant species preferences, particularly due to differences in temporal and spatial offer. However, when plant species are classified into forage classes that are continuously on offer (in space and time) at reasonable levels, comparisons between animal species should be expected to exhibit the same pattern of preferences estimated in the present study.

\section{Comparisons with Published Data}

Predicted preferences closely matched published information on diet selection when plant species were grouped into grasses, forbs, and browse classes. For 2 extensive experiments (Bryant et al. 1979, Rector 1983) in which diets for 3 of the 4 herbivore species were estimated throughout the year in the Edwards Plateau, the general pattern of preferences was coincident with that observed in the multidimensional scaling analysis (compare panels (d) and (e) in Fig. 3). Other studies (Taylor et al. 1980, McGinty et al. 1983) also confirm the relative preferences for forage classes estimated for cattle in this study.

For deer, another comparison was possible using data from 26 of the plant species for which deer preference was reported by
Armstrong (1991). He classified species as preferred, good, low quality, and little utilized forage for white-tailed deer in the Kerr Wildlife Management Area (Kerr County, Texas). Analysis of variance of the preference ranks from our data revealed significant differences $(P<0.0001)$ that followed the general trend of Armstrong's (1991) lists. Mean rankings ( \pm SE) were $14.4 \pm 7.6$, $44.2 \pm 6.7,67.4 \pm 12.3$, and $84.6 \pm 4.4$ for preferred, good, low quality, and little utilized species, respectively. Thus, general preference ranks for individual species synthesized from range sitc descriptions showed good agrcement with preferences derived from independent information.

\section{Conclusions}

A complete experimental validation of the rankings produced in this study is obviously unfeasible for the same reasons that cafeteria and free-ranging diet selection experiments are invariably fragmentary. However, general patterns of forage class preference among different herbivores and individual comparisons involving white-tailed deer diet preferences showed good agreement with previously published information. 
Results obtained through this meta-analysis can be compared with and supplement free-ranging diet selection and cafeteria experiments that rely on locally specific evaluations in which plant physiology, individual plants, and plant parts may affect preferences. For many variables of importance in range management decisions, funding is not available for experimentation at the intensity required to produce meaningful landscape-scale results. The time required to generate such information is also critical. Subjective information, in the form of expert opinion, may be readily available or can be systematically elicited (Kadane et al. 1980). This prior information can be used to translate uncertainty into probability distributions that could be updated as soon as experimental results become available. Range management would greatly benefit from the adoption of such a Bayesian approach, given the restrictions associated with gathering experimental information at adequate scales.

Preference rankings obtained from expert opinion summarize information that closely matches the scale at which management decisions will affect vegetation trends. These rankings may be less site- and season-specific and lcss prccise than rankings from experimental trials; nevertheless, they may be more capable of producing meaningful results when used to predict vegetation trends at the management unit scale. The potential utility of preference rankings for predicting changes in range vegetation, when supplemented with other comparative ecological information on individual plant species, is currently being explored (Rodríguez Iglesias 1996).

\section{Literature Cited}

Arnold, G.W. 1981. Grazing behavior. In: F.II.W. Morley (ed.). Grazing Animals. World Anim. Sci. Vol. B1. Elsevier, Amsterdam.

Armstrong, W.E. 1991. Managing habitat for white-tailed deer in the Hill Country area of Texas. Federal Aid Report Series No. 28. Texas Parks and Wildl. Dept., Wildl. Division, Austin, Tex.

Bryant, F.C., M.M. Kothmann, and L.B. Merrill. 1979. Diets of sheep, Angora goats, Spanish goats and white-tailed deer under excellent range conditions. J. Range Manage. 32:412-417.

Correl, D.S. and M.C. Johnston. 1970. Manual of the vascular plants of Texas. Texas Res. Foundation, Renner, Tex.

Gabriel, K. R. 1971. The biplot graphical display of matrices with applications to principal component analysis. Biometrika 58:453-467.

Gilmour, A.R. 1985. REG - A generalised linear models program. Division of Agricultural Services Miscellaneous Bulletin No 1. Dept. of Agr., NSW, Australia.

Gilmour, A.R., R.D. Anderson, and A.L. Rae. 1985. The analysis of binomial data by a generalized linear mixed model. Biometrika 72:593-599.

Gilmour, A.R., R.D. Anderson, and A.L. Rae. 1987. Variance components on an underlying scale for ordered multiple thresholds categorical data using a generalized linear mixed model. J. of Anim. Breeding and Genetics 104:149-155.

Gower, J.C. and D.J. Hand. 1996. Biplots. Chapman \& Hall, N. Y.

Hatch, S.L., N.G. Kancheepuram, and L.E. Brown. 1990. Checklist of the vascular plants of Texas. MP-1655. Texas Agricultural Experiment Station, College Station, Tex.

Henderson, C.R. 1984. Applications of linear models in animal breeding. University of Guelph Press, Guelph, Canada.

Hunter, J.E., F.L. Schmidt, and G.B. Jackson. 1982. Meta-analysis. Cumulating research findings across studies. Sage Pub., Beverly Hills, Calif.

Kadane, J.B., J.M. Dickey, R.L. Winkler, W.S. Smith, and S.C. Peters. 1980. Interactive elicitation of opinion for a normal linear model. J. of the Amer. Statistical Assoc. 75:845-854.

McCullagh, P. and J.A. Nelder. 1989. Generalized linear models. Chapman and Hall, London, U.K.
McGinty, A., F.E. Smeins, and L.B. Merrill. 1983. Influence of spring burning on cattle diets and performance on the Edwards Plateau. J. Range Manage. 36:175-178.

Meuwissen, T.H.E., B. Engel, and J.H.J. van der Werf. 1995. Maximizing selection efficiency for categorical traits. J. Anim. Sci. 73:1933-1939.

Nelder, J.A. and R.W.M. Wedderburn. 1972. Generalized linear models. Journal of the Royal Statistical Society, Series A 135:370-384.

Patterson, H.D. and R. Thompson. 1971. Recovery of inter-block information when block sizes are unequal. Biometrika 58:545-554.

Rector, B.S. 1983. Diet selection and voluntary forage intake by cattle, sheep, and goats grazing in different combinations. Ph.D. Diss., Texas A\&M Univ. College Station, Tex.

Robinson, G.K. 1991. That BLUP is a good thing: the estimation of random effects. Statistical Sci. 6:15-51.

Rodríguez Iglesias, R.M. 1996. A formalism for characterizing vegetation responses using classification trees and Dempster-Shafer theory of evidence. Ph.D. Diss., Texas A\&M Univ. College Station, Tex.

SAS Institute Inc. 1989. SAS/STAT User's guide, version 6. Fourth edition. SAS Institute Inc., Cary, N.C.

Statistical Sciences Inc. 1993. S-Plus user's guide. Statistical Sci. Inc., Seattle, Wash.

Straka, EJ. 1993. Preferences for redberry and blueberry juniper exhibited by cattle, sheep, and goats. M.S. Thesis, Texas A\&M Univ. College Station, Tex.

Stram, D.O. 1996. Meta-analysis of published data using a linear mixedeffects model. Biometrics 52:536-544.

Taylor, C.A., M.M. Kothmann, L.B. Merrill, and D. Elledge. 1980. Diet selection by cattle under high-intensity low-frequency, short duration, and Merrill grazing systems. J. Range Manage. 33:428-434.

Thompson, R. 1990. Generalized linear models and applications to animal breeding, p. 312-328. In: D. Gianola and K. Hammond (eds.), Advances in statistical methods for genetic improvement of livestock. Springer-Verlag, N.Y.

Weeks, D.L. and D.R. Williams. 1964. A note on the determination of connectedness in an $\mathrm{N}$-way cross-classification. Technometrics 6:319-324. 